\title{
ASSESSMENT OF ORGANOCLAY STRUCTURAL PROPERTIES AFTER GASOLINE ADSORPTION PROCESS
}

\author{
D. D. C. A. SPERIDIÃO ${ }^{1}$, O. A. ANDREO DOS $\operatorname{SANTOS}^{2}$, M. G. A. VIEIRA ${ }^{1}$ \\ ${ }^{1}$ University of Campinas, School of Chemical Engineering, Department of Processes and Products \\ Design \\ ${ }^{2}$ University of Maringá, Department of Chemical Engineering \\ E-mail melissagav@ feq.unicamp.br
}

\begin{abstract}
The removal of organic contaminants from water and wastewater is a key problem of environmental remediation which can be solved by adsorption process, especially with the use of organoclays for their abundance, variety and low cost. Therefore, this study aimed the evaluation of modifications on the structure of a commercial bentonite organoclay named Spectrogel due to the adsorption process with gasoline and isooctane. The characterization of the organoclay was accomplished through TGA, DSC, FT-IR, SEM/EDX, XRD and Helium picnometry analyzes before and after the process of gasoline removal. Modifications in the organoclay structure were verified and could be attributed to the adsorption process of the organic compounds.
\end{abstract}

\section{INTRODUCTION}

According to the Environmental Company of State of São Paulo (CETESB) 80\% of municipality of São Paulo are totally or partially dependant on underground water. Annual reports from CETESB (2012) shows that nearly $77 \%$ of identified contaminated areas of the state are due gas station activities. This follows up what the Environmental Protection Agency from USA (USEPA) surveyed on late 80's. These contaminations are from expired underground fuel storage tanks and without proper maintenance according to Tiburtius et al. (2005).

According to Wang et al. (2013) fuels like gasoline and diesel have highly toxic, carcinogenic and mutagenic additives like BTX, and if it was not bad enough the presence of alcohol worsen the risk of contamination by enhancing the mobility of all petroleum hydrocarbons on soil as studied by Adam et al. (2002). These fuels also damage the environment by changing soil permeability to water and harm the flora according to Zhang et al (2006).

Among the treatments of oily water a very promising one is the adsorption process using organoclays due their high capability to remove hydrophobic contaminants from aqueous solutions. As clays are a very abundant in nature and cheap this represents an economic advantage in the process as well.

According to Grim (1968) clays have an interlamelar cation that plays a great role on its 


\section{9 a 22 de outubro de 2014 \\ Florianópolis/SC}

physicochemical properties like viscosity, tixotropy, plasticity, mechanical resistance and affinity to polar or organic matter. Therefore, the organoclays are chemically modified clays by the exchange of its natural interlamelar inorganic cation for an organic cation, usually a quaternary alkyllamonium salt, which provides the clay a high capability to remove hydrophobic contaminants from aqueous solutions according to Kwolek et. al. ( 2003) and Alther (1995).

This study assessed the organoclay's chemical and structural properties after sorption of gasoline and isooctane for better understanding of the process and for the next studies of regeneration of this adsorbent.

\section{MATERIALS AND METHODS}

The commercial organoclay used was kindly provided by SpectroChem ${ }^{\circledR}$. This clay was milled and sieved to the average size of $0.655 \mathrm{~mm}$ of diameter for use on the sorption process.

The proportion used for sorption was $5 \mathrm{~mL}$ of contaminant per gram of organoclay while the initial concentration was $16.66 \%$ in volume. After the sorption process the organoclay was removed from solution by filtering and kept on fume hood at $20^{\circ} \mathrm{C}$ till dry.

The contaminated organoclay was milled and sieved to the sizes of $0.655 \mathrm{~mm}$ for Scanning Electron Microscopy (SEM) and Energy Dispersive X-ray (EDX) analysis and smaller than $0.075 \mathrm{~mm}$ for X-ray Diffraction (XRD), Thermogravimetric (TGA/DTG) and Differential Scanning Calorimetry (DSC) analyses.

\subsection{Equipments and Conditions}

Thermogravimetric Analyses (TG/DTG): Both analyzes were performed on equipment Shimadzu TGA-50 under a heating rate of $10^{\circ} \mathrm{C} / \mathrm{min}$ from room temperature to $1000^{\circ} \mathrm{C}$ and a $\mathrm{N}_{2}$ flow of $50 \mathrm{~mL} / \mathrm{min}$. Alpha alumina was used as the reference material for DSC analysis.

Differential scanning calorimetry (DSC): This analysis was performed using a detector Mettler-Toledo model DSC1 at a flow rate of $50 \mathrm{~mL} / \mathrm{min}$ from room temperature to $500{ }^{\circ} \mathrm{C}$ and a heating rate of $10^{\circ} \mathrm{C} / \mathrm{min}$ in nitrogen atmosphere.

X-ray diffraction (XRD): The equipment used was a Philips X'Pert model with copper Ka radiation, voltage of $40 \mathrm{kV}$ and $40 \mathrm{pA}$ current, wavelength of $1.5406 \AA$ and $2 \theta$ ranging from $3^{\circ}$ to $90^{\circ}$ at $0.02^{\circ}$ per second.

Scanning Electron Microscopy (SEM) and Energy Dispersive X-ray (EDX): The clay was immobilized on carbon tape and coated with $9.2 \mathrm{~nm}$ of gold in Sputter Coater Polaron device, Model SC7620 brand VG Microtech (Uckfield, England). Then, the sample was analyzed in Scanning Electron Microscope with Energy Dispersive Detector X-ray, Model SEM LEO 440i and EDX Model: 6070 Brand SEM / EDX: LEO Electron Microscopy under accelerating voltage $20 \mathrm{kV}$ and beam current of $100 \mathrm{pA}$ at the micrographs and $600 \mathrm{pA}$ for EDX. 


\section{9 a 22 de outubro de 2014 \\ Florianópolis/SC}

Fourier Transform Infrared Spectroscopy (FT-IR): The powder samples were compressed into $\mathrm{KBr}$ pellets and analyzed in a Thermo Scientific spectometer model Nicolet 6700 on transmittance mode ranging from 4000 to $400 \mathrm{~cm}^{-1}$ with resolution of $4 \mathrm{~cm}^{-1}$.

\section{RESULTS AND DISCUSSION}

Figure 1 shows the thermogravimetric curve (TGA) and its derivative (DTG). All curves showed a similar pattern on temperature. According to Bertagnolli et al. (2012) the first peak for DTG, under $100{ }^{\circ} \mathrm{C}$ shows the loss of moisture. This shows a lessening on the hydrophobic property after isooctane sorption due higher amount of water. The second peak, between $100{ }^{\circ} \mathrm{C}$ and $200{ }^{\circ} \mathrm{C}$, is related to interlayer water. It shows that more water was retained on interlayer spaces after gasoline adsorption while the other samples had almost none. The third and major peak for all samples, around $350{ }^{\circ} \mathrm{C}$, is due the decomposition of the organic compound according to Almeida Neto et al. (2012). It similarity suggests that the organic salt is still there, but is affected by the sorbed compounds. The isooctane, as a pure component, showed a thinner peak under the usual temperature of decomposition, while gasoline made a wider peak. The fourth peak, close to $650{ }^{\circ} \mathrm{C}$, refers to the alumino-silicate dehydroxylation and decarbonation, common for smectite clays.

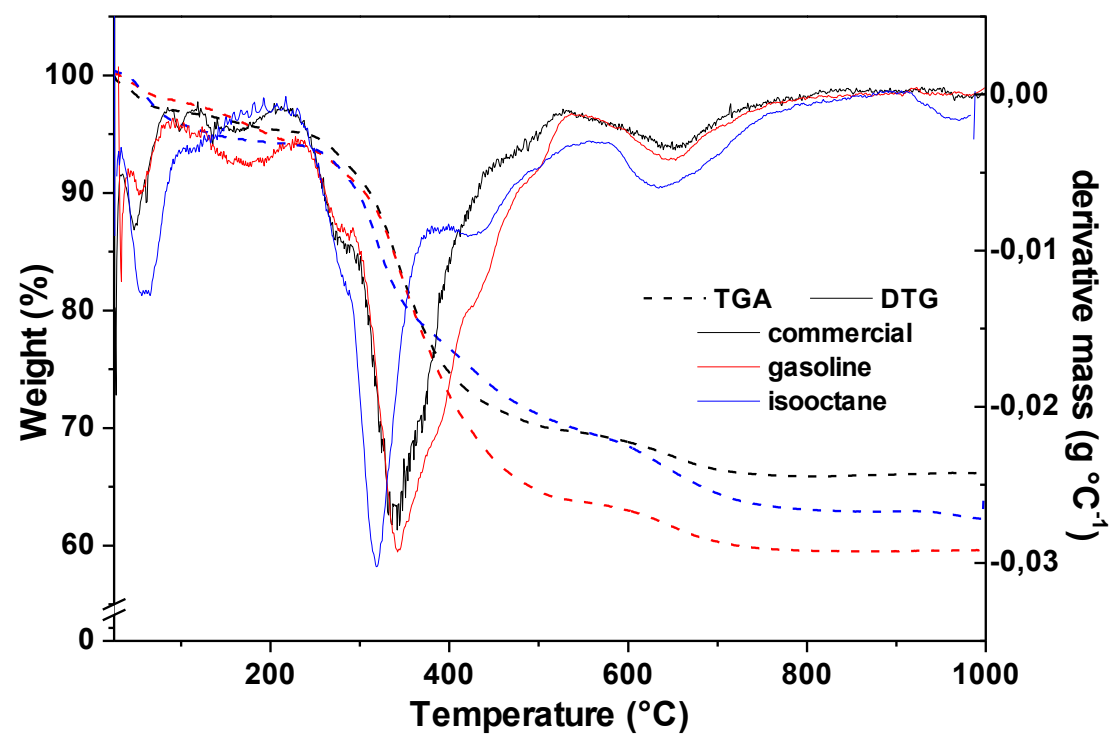

Figure 1 - Thermogravimetric analysis of commercial organoclay and contaminated organoclays.

The differential scanning calorimetry shown on Figure 2 exhibits three endothermic events. According to Almeida Neto et al. (2012) the first two peaks refers to dehydration of the clay, as observed in thermogravimetric analysis. The first peak at $50{ }^{\circ} \mathrm{C}$ is due the surface moisture and the second peak refers to interlayer moisture. The third peak, near $400{ }^{\circ} \mathrm{C}$, according to Bertagnolli et al. (2011), is due to degradation of the organic compound present in the organoclay. The gasoline curve for this region was rather flat probably due its lower vapor pressure requiring less energy to change its state. 


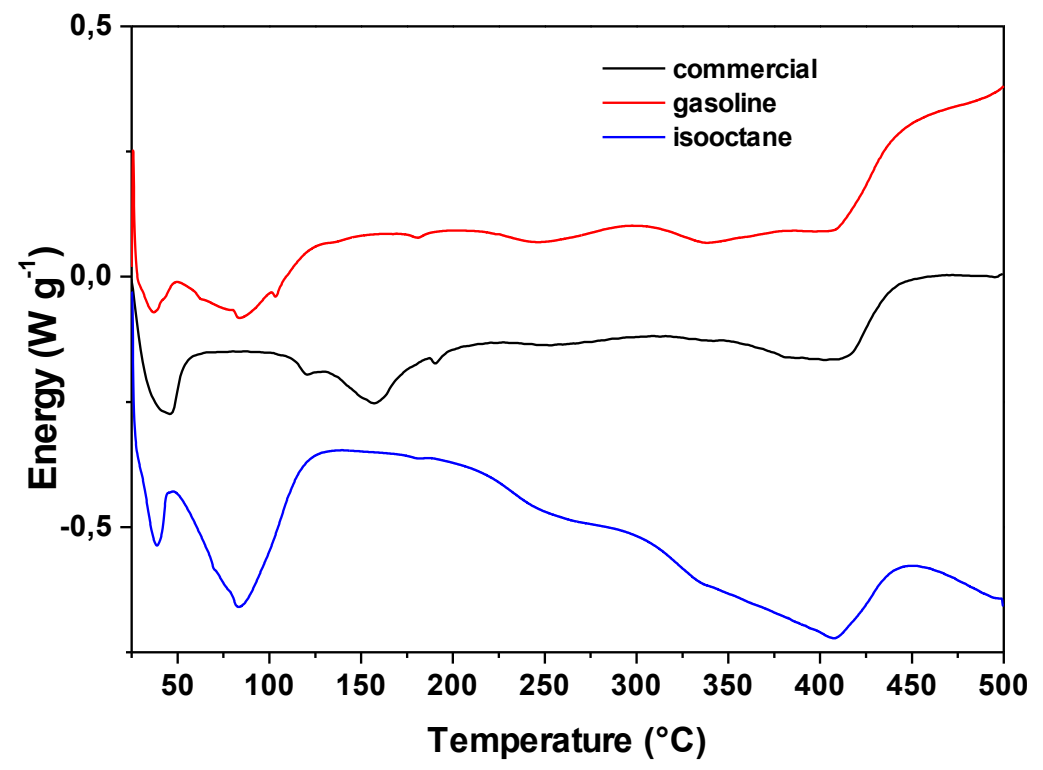

Figure 2 - Differential scanning calorimetry of commercial organoclay and contaminated organoclays.

Figure 3 shows the diffratogram for commercial organoclay and contaminated with gasoline and isooctane. As can be observed all peaks were weakened for both contaminated organoclays. The basal spacement $\mathrm{d}_{001}$ reduced from $2.05 \mathrm{~nm}$ to $1.392 \mathrm{~nm}$ after gasoline adsorption and to $1.314 \mathrm{~nm}$ after isoctane adsorption. All other peaks remained unchanged. The $\mathrm{d}_{010}(0.44 \mathrm{~nm})$ peak is typical of montmorillonite clay while the $\mathrm{d}_{060}(0.149 \mathrm{~nm})$ means a dioctaedral arrangement. The peaks of 0.33 $\mathrm{nm}$ and $0.25 \mathrm{~nm}$ belong to quartz while $0.28 \mathrm{~nm}$ and $0.20 \mathrm{~nm}$ are from mica according to Marcos et al. (2009) and Gillot (1968).

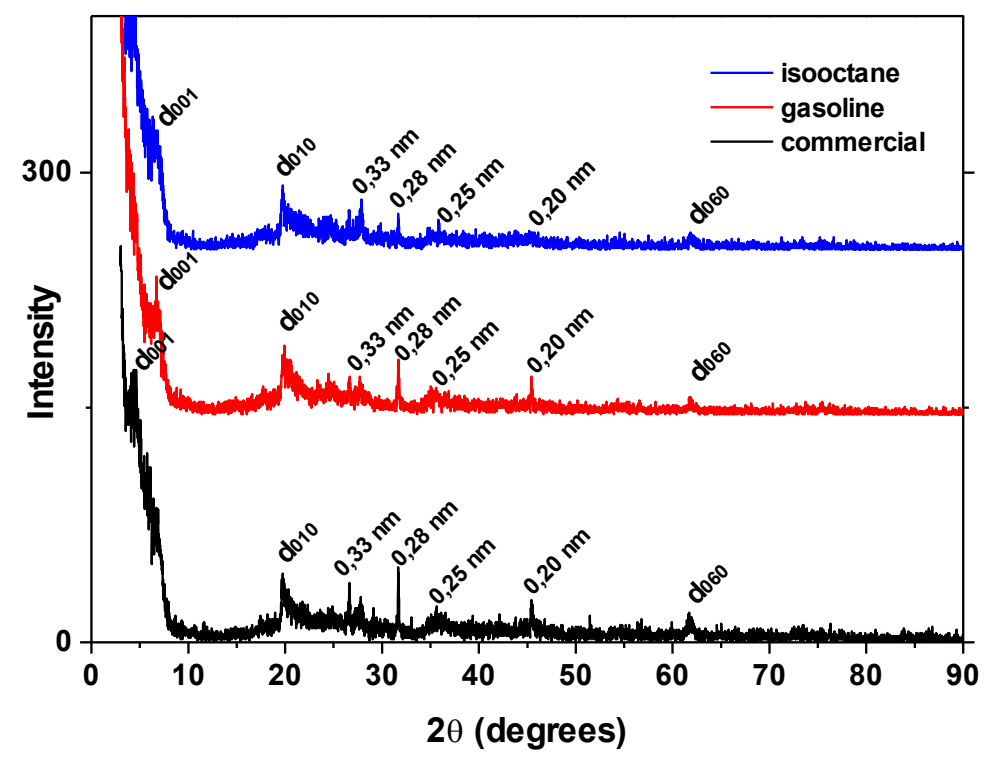

Figure 3 - Diffractograms of contaminated commercial organoclay and contaminated organoclays. 
The spectrogram is shown on Figure 4. It can be noticed the peaks of $\mathrm{CH}$ stretching band (2920 $\left.\mathrm{cm}^{-1}\right)$, the symmetrical stretching band of $\mathrm{CH}_{3}\left(2850 \mathrm{~cm}^{-1}\right)$ and the peak of scissor vibration of $\mathrm{CH}_{2}$ $\left(1470 \mathrm{~cm}^{-1}\right)$ accordingly with Bala et al. (2002) and Xi et al. (2007). According to Pereira et al. (2004), the peaks inherent of smectites $\left(3630,3440,1040,519\right.$ and $\left.461 \mathrm{~cm}^{-1}\right)$ relatives to $\mathrm{OH}$ and $\mathrm{SiO}$ can be also seen. In this aspect there were not any changes after adsorption process, but the reduction of absorbance on infrared spectrum.

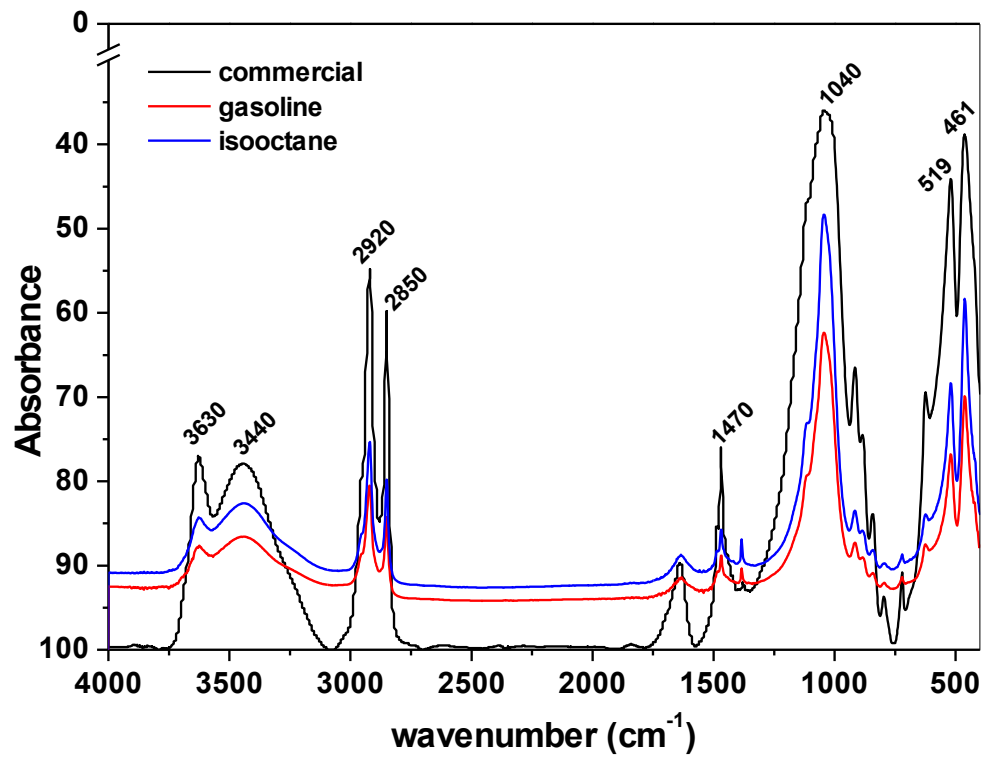

Figure 4 - FTIR spectra of the commercial clay and organoclay after sorption process.

The SEM micrographs of commercial organoclay and contaminated organoclay are shown in Figure 5. It can be observed a higher surface roughness for gasoline and isooctane compared to the commercial one.

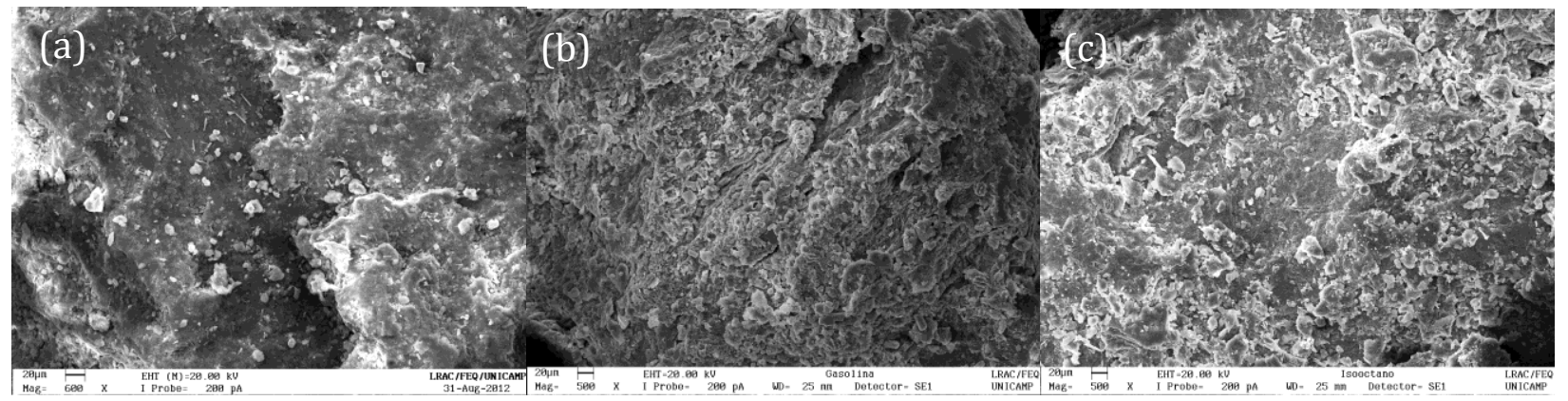

Figure 5 - Micrographs of (a) commercial, (b) gasoline and (c) isooctane organoclays at magnification of $600 x$.

Table 1 shows the mean chemical composition of organoclays assessed. As expected for montmorillonite clay, all samples are mainly composed of silica and aluminum It can be observed a 


\section{9 a 22 de outubro de 2014 \\ Florianópolis/SC}

rise on the proportion of Sodium that might be due the homogeneity of the sample as crystals of sodium chloride were present on the commertial's SEM micrographs, but not on the contaminated ones.

Table 1 - Chemical composition of organoclay samples by EDS.

\begin{tabular}{ccccccc}
\hline \multirow{2}{*}{ Sample } & \multicolumn{7}{c}{ Composition (\%) } \\
\cline { 2 - 7 } & $\mathbf{S i}$ & $\mathbf{A l}$ & $\mathbf{C l}$ & $\mathbf{F e}$ & $\mathbf{N a}$ & $\mathbf{M g}$ \\
\hline Commercial & 59.32 & 17.54 & 7.54 & 6.37 & 6.31 & 2.93 \\
Gasoline & 51.00 & 17.30 & 8.87 & 5.97 & 13.92 & 2.95 \\
Isooctane & 56.48 & 19.52 & 3.24 & 6.31 & 10.98 & 3.47 \\
\hline
\end{tabular}

The He picnometry showed an increasing density being 1.6516 g.mL $\mathrm{m}^{-1}$ the commercial, 1.6858 g. $\mathrm{mL}^{-1}$ the organoclay with isooctane and $1.7384 \mathrm{~g} \cdot \mathrm{mL}^{-1}$ the organoclay with gasoline. This could be attributed to the sorbed organic as gasoline has a higher density compared to isooctane.

The regeneration of the adsorbent contaminated of gasoline and isooctane was carried out with chemical eluents. The eluents tested were acetonitrile, methanol and ethanol (pure and diluted with water at different proportions). These eluents are compounds which have properties to desorb the contaminants. However, acetonitrile and methanol are toxic to the environment and human health. Thus, the eluent chosen to regenerate the clay was ethanol (desorption data not shown in this paper).

\section{CONCLUSIONS}

The sorbed compounds reduced the interlayer $\left(\mathrm{d}_{001}\right)$ basal spacing meaning it replaced completely or partially the organic salt or changed the arrangement of molecules in the interlayer. The contaminated organoclays showed reduced absorbance on FT-IR. The micrographs showed a rougher surface with gasoline. The picnometry of He showed higher densities after the sorption process as expected. The TGA curves showed more humidity for isooctane and a thinner peak on degradation of organic compound compared to commercial organoclay, while the gasoline contaminated organoclay showed a wider peak for being a mixture of hydrocarbons. The DSC curves showed a more intense exothermic peak for the organic decomposition for organoclay with isooctane and confirmed its higher humidity while the organoclay with gasoline showed a more steady demand of energy. This study will help in the next essays for the regeneration of this adsorbent usinh ethanol (diluted with water) as eluent.

\section{AKNOWLEDGEMENTS}

The authors thank to CNPq and FAPESP for the financial support. 


\section{9 a 22 de outubro de 2014 \\ Florianópolis/SC}

\section{REFERENCES}

ADAM, G.; GAMOH, K.; MORRIS, D.G.; DUNCAN, H. Effect of alcohol addition on the movement of petroleum hydrocarbon fuels in soil, Sci. Total Environ., v. 286, p. 15-25, 2002.

ALMEIDA NETO, A.F.; VIEIRA, M.G.A.; SILVA M.G.C., Cu(II) adsorption on modified bentonitic clays: different isotherm behaviors in static and dynamic systems, J. Mater. Res., v. 14 p. 1-14, 2012

ALTHER, G. R. Organically modified clay removes oil from water. Waste Manage., v. 15, n. 8, p. 623-628, 1995.

BALA, P.; SAMANTARAY, B.K.; SRIVASTAVA, S.K., Synthesis and characterization of Namontmorillonite-alkylammonium intercalation compounds, Mat. Res. Bull., v. 35, p. 1717-1724, 2000 .

BERTAGNOLLI, C; KLEINÜBING, S.J.; SILVA, M.G.C., Preparation and characterization of a Brazilian bentonite clay for removal of copper in porous beds, App. Clay Sci., 53 (2011) 73-79.

CETESB, Relation of contaminated and rehabilitated areas on State of São Paulo <http://www.cetesb.sp.gov.br/userfiles/file/areas-contaminadas/2012/texto-explicativo.pdf> (in portuguese)

GILLOTT J.E., Clay in Engineering Geology, Amsterdam: Elsevier Science Ltd, 1968

GRIM, R. E., Clay mineralogy New York: McGraw-Hill, 1968.

KWOLEK, T.; HODOROWICZ, M.; STADNICKA, K.; CZAPKIEWICZ, J. Adsorption isotherms of homologous alkyldimethylbenzylammonium bromides on sodium montmorillonite. J. Colloid Interf. Sci., v. 264, n. 1, p. 14-19, 2003.

MARCOS, C.; ARANGO, Y.C.; RODRIGUEZ, I., X-ray diffraction studies of the thermal behaviour of commercial vermiculites, APPL CLAY SCI, v. 42, p. 368-378, 2009.

PEREIRA, K.R.O.; HANNA, R.A.; VIANNA, M.M.G.R.; PINTO. C.A.R.; RODRIGUES, M.G.F.; VALENZUELA-DIAZ F.R. Brazilian organoclays as nanostructured sorbents of petroleum-derived hydrocarbons. Mat. Res., v. 8, p. 77-80, 2005

TIBURTIUS, E. R. L.; PERALTA-ZAMORA, P. P; EMMEL, A.; LEAL, E. S. Treatment of gasoline-contaminated waters by advanced oxidation processes. J Hazard Mater, v. 126, p. 86-90, 2005.

WANG, F., LI, C., LIU, W., JIN, Y., Oxidative damage and genotoxic effect in mice caused by subchronic exposure to low-dose volatile organic compounds, Inhal. Toxicol., v. 25, n. 5, p. 235-242, 2013.

XI, Y.; FROST, R.L.; HE, H., Modification of the surfaces of Wyoming montmorillonite by the cationic surfactants alkyl trimethyl, dialkyl dimethyl, and trialkyl methyl ammonium bromides, $J$. Colloid Interf. Sci., v. 305, p. 150-158, 2007.

ZHANG, J., ZENG, J. Sorption of diesel oil on loam s in Beijing area. Acta Sci. Circumst., v. 26 n 2 , p. 287-292, 2006. 